Article

\title{
The Effect of Tuition Fee Constraints on Financial Management: Evidence from Korean Private Universities
}

\author{
Young-Hwan Lee ${ }^{1}$, Kwon-Sik Kim ${ }^{2}$ and Kwang-Hoon Lee ${ }^{3, * \text { (D) }}$ \\ 1 Department of Social Welfare, Won-Kwang Health Science University, Iksan 54538, Korea; \\ apersonview@naver.com \\ 2 Korea Small Business Institute, Seoul 07074, Korea; kskim@kosbi.re.kr \\ 3 Department of Public Administration, Kangwon National University, Chuncheon 24341, Korea \\ * Correspondence: swiss@kangwon.ac.kr; Tel.: +82-10-5453-9125
}

Received: 13 May 2020; Accepted: 15 June 2020; Published: 22 June 2020

\begin{abstract}
This study examined the effect of tuition fee control policy on universities' financial management. Using data from 93 private universities in Korea from 2006 to 2015, we investigated the effect of tuition fees and government subsidies on labor cost, operating expenses, research expenses, and so on. Based on principal and agency theory, we used the analysis of average percentage change in expenditure and panel data analysis with the help of a Least Squares Dummy Variable (LSDV) model and polynomial regression. The results show that the increase rate of tuition fees decreased after 2011, with government subsidies increasing. The LSDV analysis indicates that universities increase labor costs, operating expenses, and student support fees, while there are no differences in research expenses, laboratory fees, and expenditures from investments and other assets. Polynomial regression reveals that, based on resources, universities behave differently in their spending. With these results, this study suggests a method to lessen information asymmetry and goal conflict, such as a performance-based research system and an incentive-based budget system in universities.
\end{abstract}

Keywords: tuition fee control policy; financial management; principal-agency model

\section{Introduction}

As tuition fees have increased over the years, they have become a cause for concern for students and families [1]. These concerns have led to a call for attention on government policy to address tuition fee escalation. Recently, tuition fees have become one of the most pressing issues in higher education [2]. Multiple studies have explained the driving factors of tuition fee increase, such as the reduction of state appropriations and the increase of institutional spending on services, facilities, and compensation [3]. Among these, the reduction of government appropriations has been recognized as a major contributing factor of tuition fee increase [4,5].

In South Korea (hereafter Korea), the situation is different from in other countries. University tuition fees have increased by more than the inflation rate from 2000 to 2010. Similar to other countries, the fee increase has led to parents and students being concerned and becoming the targets of political and social controversy. Finally, in 2011, the Higher Education Act of Korea was amended to restrict the increase rate of tuition fees to be below a certain level. Since 2011, a few universities reduced their tuition fees by about $5-10 \%$. While the government began controlling the increase of tuition fees, it also increased its financial support to universities through government subsidies using formula funding, which has since been reinforced. As Kim and Ko [2] indicate, tuition control policy is most 
effective when it is linked with financial aid and provides incentives to limit tuition fee increase; Korean universities tend to follow tuition control policy in order to receive government financial aid.

However, as the expectations placed on universities are on the rise [6], the demands for financial expenditure have also increased. This coupling of tuition fee control and the increased demands presents a significant challenge to higher education institutions in Korea. This challenge is particularly problematic for Korean universities, for which tuition fees form the vast majority of institutional operating budgets, and which have limited the options to create other revenues. In particular, the decline of school-age populations has become a serious burden to universities, whose finances significantly depend on tuition fees. Although universities are making an effort to diversify their sources of financing, in reality, it is not easy for universities to create new sources of revenue. In this situation, it is desirable for universities to set their financial priority on student performance, which is important for formula funding to receive government financial support and for reserved students. As part of their efforts to attract reserved students, universities have to allot their expenditure on student services and education. However, under such financial constraints, this can lead to cuts in spending on student education. This approach is frequently undertaken in the name of cost reduction by decreasing course and program offerings and by reducing library and student services [7]. It has been argued that cuts in these areas negatively impact the quality of education and the university's reputation, and impair the core mission of research, teaching, and service [8]. It is necessary to empirically analyze the impact of tuition fee control policy on internal financial management. Thus far, numerous studies have investigated the factors of tuition fee increase $[4,9]$, the impact of tuition control policy [2], and the effect of tuition fees on university attendance [10]. However, there is limited knowledge about the effects of tuition fee policy on university financial management.

This study examines the characteristics of income and expenditure in university finances with respect to tuition fee control policy. Specifically, this study explores which expenditures have been reduced and which are being maintained or have increased, and how the characteristics of financial management in universities have changed after tuition fee control. In analyzing these issues, this study uses the principal-agency theory, which is an appropriate framework for analyzing the relationship between government and universities [11]. Using this theory, this study examines whether there are opportunistic behaviors or moral hazard from the agent.

To enhance a university's competitiveness, provide high-quality education, and increase financial sustainability $[12,13]$, it is necessary to efficiently and stably manage the university's finances. Financial management in universities, as a key area of university management, can be defined as a series of economic activities by universities in order to secure, distribute, spend, and evaluate finances necessary for producing and supplying higher education services to fulfill educational purposes. This study investigates the link between tuition fee control and the financial management of universities. By analyzing the impact of tuition fee control policy on the university's financial management, the study shows how universities respond strategically to fiscal constraints. In doing so, it will enhance our understanding of financial management in universities as well as universities' behavioral characteristics. In addition, it is expected to provide a new perspective on the universities' strategic behaviors.

The rest of this study is organized as follows: Section two reviews prior literature about tuition fee policy and its effect on universities. Section three discusses Korean tuition fee policy and the theoretical framework. Section four describes the data. The estimation method is presented in the fifth section, while the sixth section presents the results and identifies the main policy implications. The final section provides the conclusions.

\section{Literature Review}

As tuition price increase has accelerated beyond inflation and family incomes, tuition policy has become a pressing policy issue in higher education [2]. College prices and costs have become a major political issue at the national level [14]. Along with policy concerns about tuition, the academic community has made various efforts to address this issue. Focusing on tuition setting is a complex 
and ambiguous process, and numerous studies have explored the factors that influence the level of tuition fees. For example, Mumper [3] investigated the driving factors of tuition fee increase, such as reduced state appropriation and increased institutional spending on services, facilities, and compensation. Haptman [4] explained tuition fee increases as being caused by consumer prices, the use of expanded and improved services, and so on. While these studies focused on the factors of tuition fee increase, other studies examined the effects of state policies on tuition fee control, such as curbs, caps, and freezes [15], as well as financial aid and incentives [16]. For example, Kim and Ko [2] analyzed the impacts of state control polices on college tuition fee increase using data from 50 states and 540 public four-year universities and colleges. Using hierarchical multiple regression analysis, they examined the effects of state policy on tuition change and concluded that linking tuition to financial aid and providing incentives to limit the tuition fee increase are effective in controlling tuition fees. Interestingly, this study provides the evidence that the state's tuition cap policy can adversely affect tuition.

Several studies investigated the effects of tuition fees on university attendance [10,17], enrollment [18], intentions of degree [19], and quality [20]. Dearden et al. [10] studied participation rates with respect to the level of tuition fees in the UK. Using fixed effects regression, they found that fees have a significant adverse effect on university participation. Yoo [21] reported that introducing the half-price tuition policy in Korea is against the benefit principle and creates the contradiction of high school graduates supporting college graduates. He stated that this regulation causes side effects, such as increased youth unemployment due to academic inflation, delays in the restructuring of insolvent colleges, an increase in repeaters due to excess demand for college education, and an increase in private education expenses. Görgen et al. [18] investigated the effect of the introduction of tuition fees on university student enrollment behavior. In order to identify potentially relevant factors and control in a short time frame, this study used the Lasso technique and used spatial cross-effects in a fixed effects panel model for the enrollment analysis. Using this methodology, this study presented significant negative effects of tuition fees, inducing an up to $4.5 \%$ percentage point reduction in enrollment rates. Bahrs and Siedler [19] analyzed the effect of tuition fees on the intention to acquire a university degree. Using data from Youth Questionnaire of the German Socio-Economic Panel, they analyzed the different effects of the introduction and elimination of university tuition fees in Germany with difference-in-difference settings. The result showed that tuition fees have a negative effect on the intention of 17-year-olds to acquire a higher educational degree. Gawellek et al. [20] examined the impact of the introduction of modest tuition fees on perceived instructional quality. To analyze the effect of tuition fees on instructional evaluation ratings, they adopted the difference-in-difference method and found that the instruction of fees in a publicly financed system has a significantly positive impact on faculty evaluation.

If these studies focused on the effects of tuition fee policy, others investigated financial management in universities under fiscal constraints. Government pressure and control of tuition fees combined with decreased government funding have led universities into an unprecedented situation [22]. Responding to this situation, universities have been motivated to seek alternative revenues from research funding [23], donations, and financial investment [24]. In addition to these efforts, universities have modified their budget systems from incremental budget systems to decentralized budget models. A number of universities have adopted responsibility center management (RCM), which devolves both budget responsibility and decision-making authority in ways that motivate lower-level actors to meet larger organizational goals [7]. Using RCM, universities aim to increase the responsibilities of organizational subunits by devolving ownership of revenues and costs to encourage revenue generation and cost effectiveness, as well as enhance transparency about budget allocation and financial flexibility [25]. Accordingly, numerous studies have examined the implementation challenges of $\operatorname{RCM}[7,26]$, its benefits and drawbacks [27,28], and its effect on revenue and student satisfaction [25,29]. For example, Ozan et al. [29] analyzed the effect of RCM adoption on tuition revenue at four public universities, namely Iowa State University, Kent State University, the University of Cincinnati, and the 
University of Florida. Using the synthetic control method approach, they concluded that RCM positively affected tuition revenue at all universities except the University of Florida.

Previous studies have provided valuable insights to universities by analyzing the tuition control policy, its effects, and universities' financial management under fiscal constraints. However, to the best of our knowledge, no empirical research has established a causal link between tuition control policy and university financial management. This study aims to analyze the effect of tuition control policy on university financial management using the principal-agent model. Until now, multiple studies have analyzed the relationship between government and university by applying the principal-agent model [30-32]. For example, Liefner [30] analyzed the form of resource allocation and performance in universities using the principle-agent theory. He attempted to explain who the principal and agent are in higher education from a theoretical perspective, and recognized that the assumptions concerning goal conflicts and information asymmetries are especially relevant in the higher education context. Gornitzka et al. [32] introduced the principal-agent theory between state and higher education and analyzed the sphere of contract arrangements between state and higher education institutions. Using concepts such as moral hazard and information asymmetry, they analyzed the contract arrangements in Finland, Sweden, and Denmark. The major concepts of principal-agent theory can help in understanding the relationship between government and universities, including university administration. This theory also provides a better understanding of the problems and implications for university management.

\section{Theoretical Background}

\subsection{University Accounting System in Korea}

To analyze the effect of tuition fee and government financial support on university financial management, it is necessary to understand accounting systems in Korean private universities. There are external rules governing the operation of university finance. "Special Rules on the Finance and Accounting for Private Universities" are the accounting standards currently applied to private universities. According to this regulation, universities have to produce financial statements, such as balance sheets, statements of revenues and expenses, and statements of fund flow (Figure 1). In making financial statements, the principle of double-entry book-keeping, principle of continuity, and principle of clarity are applied.

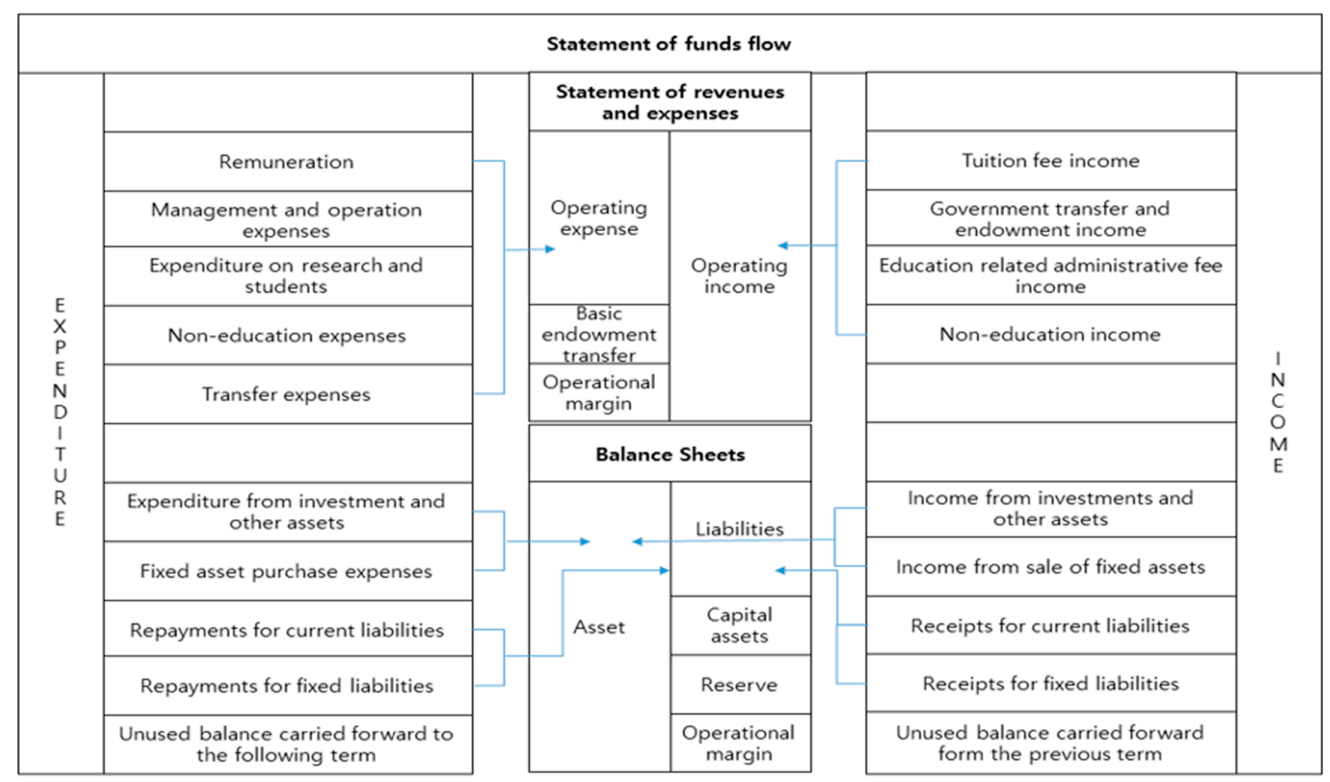

Figure 1. The structure of financial statements of private universities in Korea. 


\subsection{Korean University Tuition Policy, Government Subsidy Mechanism}

In Korea, the fundamental philosophy and policy direction of university tuition fees have been affected by the government's university education policy in 2003. At the time, the Korean government liberalized the tuition fees of all national universities. Accordingly, university tuition fee increase rates were remarkably high in the early 2000s.

Beginning in 2009, the government began controlling the increase of university tuition fees, and thus, the rates of increase have been slowing down. One of the biggest complaints of education consumers regarding university tuition fee policy is that the portion of tuition fees takes up too much of a university's finances and that there is an unequal financial burden between the university's founders and beneficiaries. Moreover, due to the lack of persuasive tuition fee appropriation methods, the grounds for appropriation are vague, and education consumers have many complaints about the unclear appropriation and operation process due to supplier-led tuition fee policy management [33].

Finally, considering the effect on prices, the government put a ceiling on tuition fee increases and revised the Higher Education Act. According to the Higher Education Act: "No school shall set the rate of increase in tuition fees at a level exceeding 1.5 times the average consumer price inflation for the three preceding years". Furthermore, the Ministry of Education has implemented a tuition fee control policy through state scholarships and a financial support project. To receive a state scholarship, it is necessary to freeze tuition fees at the least. Students can receive more state scholarships only if universities make constant efforts to reduce tuition fees or increase scholarships [34].

In addition, the government uses financial support as a tool for university control. Around 2010, the government increased the amount of financial support to universities and changed the way to distribute financial support. "Formula funding" and "block grant" schemes were implemented, and the rate of tuition increase rate was used as the key indicator in the selection process for support recipients. In this situation, universities may not be able to raise tuition fees and may be requested to lower their tuition fees. Combined with tuition fee control, universities face an unprecedented situation-a decline in school-age population. Due to the dramatic decline of the school-age population, the school-age population saw an $11.3 \%$ decrease in 2018 compared to 2013 , and the increase rate of student numbers in private universities is lower than in public universities (Figure 2).

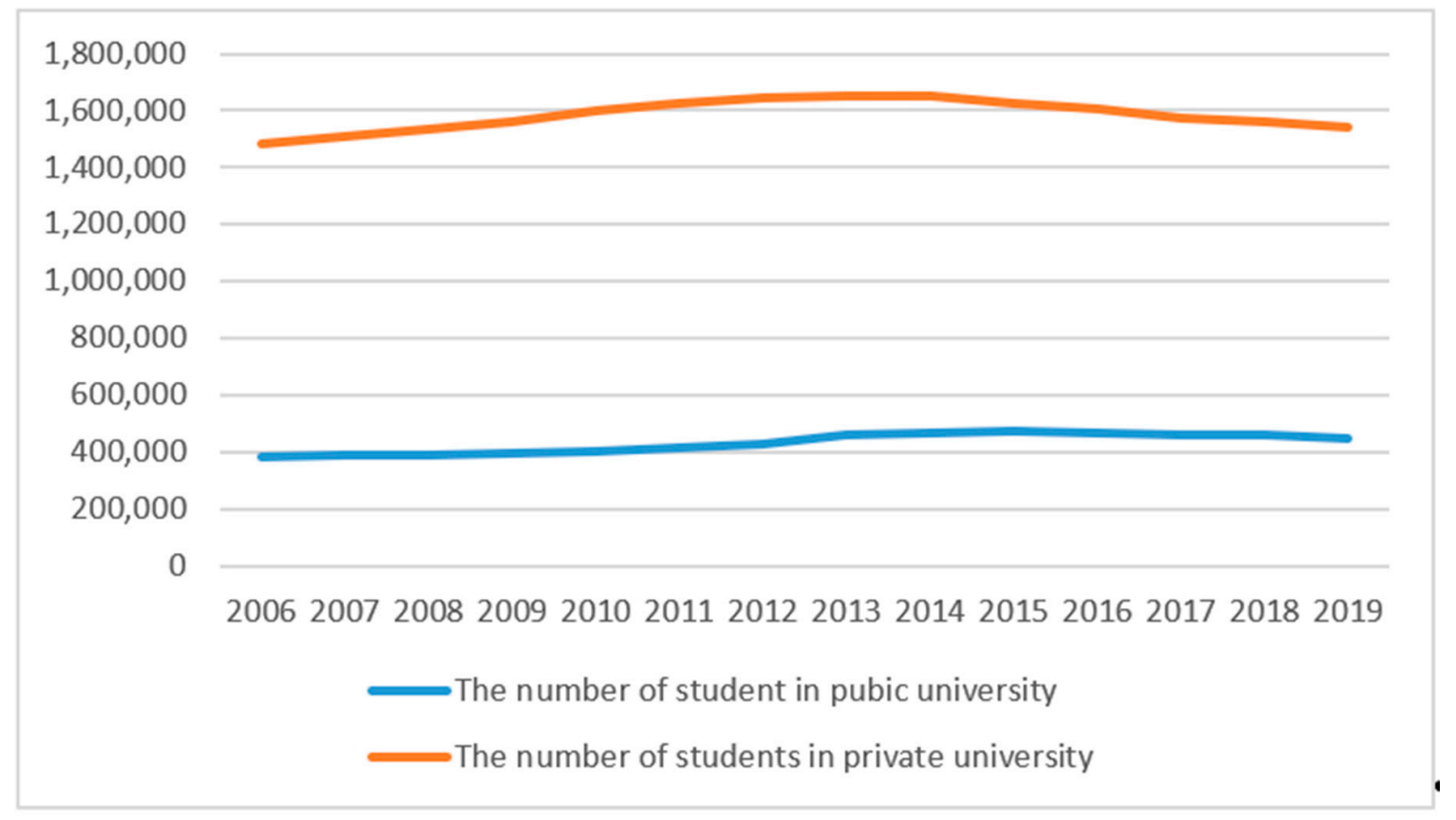

Figure 2. The number of students in private and public universities in Korea. Source: Korean Education statistic service, https://kess.kedi.re.kr/eng/index. 
These trends will be a burden to universities because most of a university's income depends on tuition fees. This decrease will translate into a financial burden to universities. Attaining government projects has thus emerged as a major goal for universities to secure; government subsides have become a major factor for the survival and sustainability of universities.

The financial structure of Korean universities is highly dependent on tuition fee income, while the ratio of government income has been increasing in recent years. In 2006, the tuition fee income from all private universities was 11,042,157 million KRW, which accounted for $68.8 \%$ of all income. In 2006, transfer and endowment income was 1,696,934 million KRW, which was 10.6\%. However, in 2015, tuition fee income was 13,657,620 million KRW (56.9\%), while transfer and endowment income was $5,712,058$ million KRW (23.8\%). The ratio of transfer and endowment income seems to have increased due to the increase of government subsidies (Table 1).

Table 1. Annual income of private universities (Unit: million KRW).

\begin{tabular}{|c|c|c|c|c|c|}
\hline Category & 2006 & 2007 & 2008 & 2009 & 2010 \\
\hline Tuition fee income & $11,042,157$ & $11,740,739$ & $12,670,596$ & $13,160,818$ & $13,735,532$ \\
\hline $\begin{array}{l}\text { Government transfer and } \\
\text { endowment income }\end{array}$ & $1,696,934$ & $1,872,182$ & $2,001,802$ & $2,531,757$ & $2,619,801$ \\
\hline $\begin{array}{c}\text { Education-related } \\
\text { administrative fee income }\end{array}$ & 423,100 & 479,569 & 536,024 & 625,224 & 718,247 \\
\hline Non-education income & 637,659 & 756,620 & 832,873 & 878,081 & 806,131 \\
\hline $\begin{array}{l}\text { Income from investments and } \\
\text { other assets }\end{array}$ & 773,985 & 993,405 & 744,290 & 895,250 & 980,278 \\
\hline Income from sale of fixed assets & 94,701 & 89,610 & 41,390 & 28,896 & 36,678 \\
\hline Receipts for current liabilities & 2057 & 2090 & 3043 & 644 & 2644 \\
\hline Receipts for fixed liabilities & 102,857 & 98,865 & 186,425 & 150,581 & 203,458 \\
\hline $\begin{array}{l}\text { Unused balance carried forward } \\
\text { from the previous term }\end{array}$ & $1,256,314$ & $1,241,322$ & $1,450,637$ & $1,744,106$ & $1,864,169$ \\
\hline Category & 2011 & 2012 & 2013 & 2014 & 2015 \\
\hline Tuition fee income & $13,724,007$ & $13,781,492$ & $13,725,653$ & $13,395,827$ & $13,657,620$ \\
\hline $\begin{array}{c}\text { Transfer and endowment } \\
\text { income }\end{array}$ & $2,704,543$ & $3,994,669$ & $4,686,934$ & $5,168,779$ & $5,712,058$ \\
\hline $\begin{array}{l}\text { Education-related } \\
\text { administrative fee income }\end{array}$ & 766,296 & 924,573 & 990,304 & $1,004,594$ & $1,079,303$ \\
\hline Non-education income & 803,171 & 739,496 & 578,832 & 547,841 & 425,648 \\
\hline $\begin{array}{l}\text { Income from investments and } \\
\text { other assets }\end{array}$ & $1,629,779$ & $1,230,731$ & $1,082,146$ & $1,348,758$ & $1,404,353$ \\
\hline Income from sale of fixed assets & 25,073 & 65,699 & 59,364 & 156,265 & 155,745 \\
\hline Receipts for current liabilities & 635,149 & 345,378 & 2865 & 1466 & 1538 \\
\hline Receipts for fixed liabilities & 239,273 & 137,209 & 220,868 & 180,160 & 169,693 \\
\hline $\begin{array}{l}\text { Unused balance carried forward } \\
\text { from the previous term }\end{array}$ & $1,852,146$ & $2,144,458$ & $1,950,733$ & $1,448,032$ & $1,335,294$ \\
\hline
\end{tabular}

Source: Private School Financial Data System.

Regarding expenditure, in 2006, remuneration was 6,078,237 million KRW, which accounted for $37.9 \%$ of all expenditures, and management and operating expenses were 1,683,451 million KRW, which was 10.5\%. Expenditure on research and students was 2,846,651 million KRW (17.7\%) in 2006. However, in 2015, remuneration was 9,299,141 million KRW (38.8\%), management and operating expense was 2,532,611 million KRW (10.5\%), and expenditure on research and students was $7,527,429$ million KRW (31.4\%). This rapid increase in expenditure on research and students may have been due to the increase in state scholarships (Table 2). 
Table 2. Annual expenditures of private universities (Unit: million KRW).

\begin{tabular}{|c|c|c|c|c|c|}
\hline Category & 2006 & 2007 & 2008 & 2009 & 2010 \\
\hline Remuneration & $6,078,237$ & $6,326,260$ & $6,818,692$ & $7,273,686$ & $7,735,373$ \\
\hline Management and operating expenses & $1,683,451$ & $1,830,510$ & $1,998,206$ & $2,131,326$ & $2,304,174$ \\
\hline Expenditure on research and students & $2,846,651$ & $3,141,699$ & $3,476,399$ & $4,017,846$ & $4,270,347$ \\
\hline Non-education expenses & 147,816 & 152,705 & 169,697 & 205,459 & 176,330 \\
\hline Transfer expenses & 23,793 & 17,436 & 14,682 & 31,671 & 29,612 \\
\hline $\begin{array}{c}\text { Expenditure from investments and } \\
\text { other assets }\end{array}$ & $1,464,843$ & $1,755,249$ & $1,770,188$ & $1,895,335$ & $1,761,906$ \\
\hline Fixed asset purchase expenses & $2,345,657$ & $2,465,258$ & $2,458,940$ & $2,483,390$ & $2,603,733$ \\
\hline Repayments for current liabilities & 11,512 & 10,968 & 14,302 & 12,282 & 17,301 \\
\hline Repayments for fixed liabilities & 101,982 & 133,637 & 118,034 & 114,185 & 112,007 \\
\hline $\begin{array}{l}\text { Unused balance carried forward to } \\
\text { the following term }\end{array}$ & $1,325,820$ & $1,440,680$ & $1,627,939$ & $1,850,177$ & $1,974,108$ \\
\hline Category & 2011 & 2012 & 2013 & 2014 & 2015 \\
\hline Remuneration & $7,966,689$ & $8,590,134$ & $8,895,711$ & $8,865,079$ & $9,299,141$ \\
\hline Management and operating expenses & $2,420,198$ & $2,536,298$ & $2,531,540$ & $2,477,145$ & $2,532,611$ \\
\hline Expenditure for research and students & $4,570,886$ & $5,851,675$ & $6,607,738$ & $7,039,274$ & $7,527,429$ \\
\hline Non-education expenses & 160,657 & 125,146 & 111,182 & 100,329 & 93,943 \\
\hline Transfer expenses & 16,061 & 4413 & 5188 & 6001 & 6485 \\
\hline $\begin{array}{c}\text { Expenditure from investments and } \\
\text { other assets }\end{array}$ & $1,884,229$ & $1,294,934$ & $1,224,080$ & $1,354,988$ & $1,417,681$ \\
\hline Fixed asset purchase expenses & $2,568,536$ & $2,528,381$ & $2,208,582$ & $2,097,255$ & $1,799,602$ \\
\hline Repayments for current liabilities & 8244 & 8570 & 10,091 & 14,829 & 23,231 \\
\hline Repayments for fixed liabilities & 168,805 & 150,449 & 142,292 & 227,812 & 144,819 \\
\hline $\begin{array}{l}\text { Unused balance carried forward to } \\
\text { the following term }\end{array}$ & $1,997,045$ & $1,950,127$ & $1,562,814$ & $1,272,696$ & $1,119,711$ \\
\hline
\end{tabular}

Source: Private School Financial Data System.

\subsection{Conceptual Framework}

This study aims to examine the characteristics of financial management in universities with regard to constraints on tuition fees and increase of government subsidies using the agency theory, which originates from studies by Ross [35] and Jensen and Meckling [36]. Traditionally, the principalagent relationship is regarded as a contractual relationship [36]. In a comprehensive sense, the agency problem is caused when a certain agent depends on the action of another person in a principal-agent relationship [37]. The principal-agent relationship is a general phenomenon and "a pervasive fact of economic life" [38]. Jensen and Meckling [36] indicated that the principal-agent relationship exists in all organizations and cooperative activities, such as corporate management, universities, conferences, and government agencies.

In the relationship between state and university, states are considered to be the principal because the governments delegate the state's educational goals to universities [39]. Universities were formed and funded by the government to fulfill the need of society to create, preserve, and transmit knowledge. The agent problem arises when (a) the principal and the agent have conflicting goals and/or (b) there is information asymmetry between them. Universities perform diverse functions, and the organizational goals of universities are complicated, ambiguous, and dynamic. Moreover, universities with multiple groups that have different interests [40] reinforce goal conflict within universities. Information asymmetry arises when the principal lacks information about the agent's work. Universities use diverse and complicated mechanisms in their production [41], and use intensive technology that requires various skills. Universities have the characteristics of joint production, in which various outputs are produced at once [42]. Due to these characteristics, the process through which professors produce and provide knowledge is difficult to monitor and control [30]. These factors lead to information asymmetry. 
Goal conflict and information asymmetry activate the possibility of agent problems, such as adverse selection and moral hazard. These problems can be illustrated using the model of revenue theory of cost [43] and the utility-maximizing models [44]. For example, the revenue theory of cost model assumes that universities raise as much money as they can and then spend it all.

In the context of the government-university relationship, the principal-agent theory could provide a useful and applicable framework for analyzing the effects of tuition fee policy on university financial management. Agency problems that may occur in the relationship between government and university or management staff and students in universities include shirking, budget maximization, and cross-subsidization [10]. Shirking is classified into passive shirking, in which the school does not achieve the objective pursued by the government and students, and aggressive shirking, in which the school acts contrary to the objective desired by the government and students [45]. Some examples include professors doing personal consulting rather than focusing on education and research for students, or the university excessively using the budget on publicity and events rather than investing in education and research. There are many accounts related to shirking in the expenditure accounts of universities in Korea. First, operating expenses include welfare benefits, training costs for faculty and staff, general service costs, business operating expenses, publicity costs, meeting costs, event costs, missionary work costs, and other operating expenses, which are costs related to the management of the university rather than costs invested to meet the purposes desired by the government and students, and thus, excessive spending on these items can be regarded as a form of shirking. Expenditure from investments and other assets is also an account to increase the financial income activities of universities rather than investment in education and research. The pursuit of a greater budget involves the act of making efforts to constantly increase the budget and to spend it. This can be determined by the variation of unused balance carried forward to the following term. In cross-subsidization, the budget that must be used for students' education is, in fact, used for the university's management or operations. This includes spending the budget that must be invested in education and research on constructing or buying a new school building, implementing a computer system to reduce the workload of administrative staff, or increasing labor costs [22]. Accordingly, the analysis in this study will be conducted by setting the following research question and hypotheses. Research Question: What are the characteristics of university financial management with regard to tuition control policy? Do universities act with moral hazard in their financial management? To analyze this research question, this study constructs the following hypotheses.

Hypothesis 1. Universities will display shirking behavior despite tuition fee constraints.

Hypothesis 2. Universities will display budget maximization behavior despite tuition fee constraints.

Hypothesis 3. Universities will display cross-subsidization behavior despite tuition fee constraints.

\section{Research Design}

\subsection{Data}

This study analyzed private universities in Korea because private universities account for $80 \%$ of higher education in Korea, and are under relatively tighter constraints on financial management than national universities. The period of analysis is from 2006 to 2015, because the regulations on tuition fee increase rates in the Higher Education Act were amended in September 2011, and there is a difference in tuition fee increase rates before and after 2011. Although the number of universities slightly varied by year, there were around 93 universities. 
This study analyzed the characteristics of financial management in universities based on the account of university expenditure. Information on the account of university expenditure was obtained from the financial statements of universities. The financial statement of a university includes balance sheets, statements of revenues and expenses, and statements of funds flow. This study analyzed the financial characteristics using the statements of funds flow because this statement presents a university's fund income and spending for a certain period. Data regarding the funds flow were collected from the Private School Financial Data System.

In analyzing the effect of tuition fee control, this study uses tuition fees and government subsidies as the explanatory variables because the government started controlling tuition fees with the increase of financial support to universities. As the dependent variables, this study uses expenditure from investments and other assets, fixed asset purchase expenses, and labor costs, among others. Through these variables, we can explore the characteristics of universities' financial management under the tuition fee control policy. For example, operating expenses include welfare benefits, training costs for faculty and staff, general service costs, business operating expenses, publicity costs, meeting costs, event costs, missionary work costs, and other operating expenses related to the management of the university, rather than the costs invested to meet the purposes desired by students; therefore, excessive spending on these items can be regarded as a form of moral hazard. In addition, expenditure from investments and other assets also results in increasing the financial income activities of universities rather than investment in education and research. The pursuit of a greater budget involves making efforts to constantly increase the budget and expenditure. This can be determined by the variation of unused balance carried forward to the following term. Table 3 provides a list of the control variables, independent variables, and dependent variables used in this study.

Table 3. Variables and contents of analysis.

\begin{tabular}{|c|c|c|}
\hline Category & Variable & Note \\
\hline Control variables & $\begin{array}{l}\text { Fiscal year: } 2006-2015 \\
\text { Size: Fewer than } 5000 \text { students }=1,5000 \text { to fewer than } \\
10,000 \text { students }=2,10,000 \text { students and more }=3 \\
\text { Finance size: Fewer than } 10 \text { billion KRW }=1 \text {, } \\
10 \text { billion KRW to fewer than } 50 \text { billion KRW }=2, \\
50 \text { billion to } 100 \text { billion } \mathrm{KRW}=3,100 \text { billion } \mathrm{KRW} \text { to } \\
200 \text { billion KRW }=4,200 \text { billion KRW and more }=5 \\
\text { University establishment year }\end{array}$ & \\
\hline Independent variables & $\begin{array}{l}\text { Tuition fee } \\
\text { Government subsidies }\end{array}$ & \\
\hline Dependent variables & $\begin{array}{l}\text { Operating expenses } \\
\text { Expenditure from investments and other assets } \\
\text { Fixed asset purchase expenses } \\
\text { Unused balance carried forward to the following term } \\
\text { Labor costs } \\
\text { Research expenses } \\
\text { Laboratory fees } \\
\text { Student support fees }\end{array}$ & $\begin{array}{l}\text { shirking } \\
\text { shirking } \\
\text { shirking } \\
\text { budget maximization } \\
\text { cross-subsidization } \\
\text { cross-subsidization } \\
\text { cross-subsidization } \\
\text { cross-subsidization }\end{array}$ \\
\hline
\end{tabular}

The mean value of tuition fees is $93,513,167 \mathrm{KRW}$ (one US dollar is equivalent to 1180 Korean won) and the mean value of government subsidies is 9,853,121 KRW. Among the expenditures, labor costs make up the largest portion (see Table 4). 
Table 4. Descriptive statistics. (Unit: 1000 KWR).

\begin{tabular}{cccc}
\hline & Mean & Min. & Max. \\
\hline Tuition fees & $93,513,167$ & $7,366,817$ & $383,330,038$ \\
Government subsidies & $9,853,121$ & 1 & $66,359,084$ \\
Labor costs & $60,953,790$ & $4,532,384$ & $482,828,806$ \\
Operating expenses & $16,242,164$ & $1,443,113$ & $123,557,121$ \\
Research expenses & $4,221,199$ & 1 & $79,950,857$ \\
Laboratory fees & $1,801,100$ & 56,887 & $9,283,436$ \\
Student support fees & $2,658,183$ & 5029 & $22,782,981$ \\
Expenditure from investments & $12,704,207$ & 1 & $180,521,886$ \\
and other assets & $17,184,608$ & 220,055 & $142,486,789$ \\
Fixed asset purchase expenses & $8,764,900$ & 1 & $120,581,735$ \\
Unused balance carried & & & \\
forward to the following term & & & \\
\hline
\end{tabular}

\subsection{Method of Analysis}

To analyze the effects of tuition fee control policy on university financial operation, this study used panel data. Before using the panel data regression model, this study tests the stationarity of the data. The results of the LLC (Levin, Lin and Chu [46]) panel unit root test and Fisher stationary test indicate that all variables satisfy data stationarity at the level of trans-log variables (see Table 5).

Table 5. Results of unit root test.

\begin{tabular}{|c|c|c|c|}
\hline & Variable & LLC & Fisher \\
\hline \multirow{10}{*}{ Label variables } & Tuition fees & $-5.0838^{* * *}$ & $4.5162 * * *$ \\
\hline & Government subsidies & 5.5706 & $7.8925 * * *$ \\
\hline & Labor costs & $-1.4675^{*}$ & $0.2549^{* * *}$ \\
\hline & Operating expenses & $-4.0846^{* * *}$ & $1.7872 * *$ \\
\hline & Research expenses & $-10.3454^{* * *}$ & $3.9814^{* * *}$ \\
\hline & Laboratory fees & $-5.2519^{* * *}$ & 6.2017 \\
\hline & Student support fees & $-2.5769 * *$ & $2.5867^{* *}$ \\
\hline & Expenditure from investments and other assets & $-23.0822 * * *$ & $6.4828^{* * *}$ \\
\hline & Fixed asset purchase expenses & $-9.0398^{* * *}$ & $9.3314 * * *$ \\
\hline & $\begin{array}{l}\text { Unused balance carried forward to the } \\
\text { following term }\end{array}$ & $-8.3428^{* * *}$ & $2.9690 * *$ \\
\hline \multirow{10}{*}{ Log-trans variables } & Tuition fee & $-5.8952^{* * *}$ & $8.9989 * * *$ \\
\hline & Government subsidies & $-26.1368^{* * *}$ & $14.2754^{* * *}$ \\
\hline & Labor costs & $-3.6059 * * *$ & $3.4120 * * *$ \\
\hline & Operating expenses & $-9.0974^{* * *}$ & $1.8012^{* *}$ \\
\hline & Research expenses & $-5.3402 * * *$ & $2.0106^{* * *}$ \\
\hline & Laboratory fees & $-6.4330^{* * *}$ & $8.4936^{* * *}$ \\
\hline & Student support fees & $-5.2303^{* * *}$ & $1.3841^{* *}$ \\
\hline & Expenditure from investments and other assets & $-12.3069^{* * *}$ & $10.6963^{* * *}$ \\
\hline & Fixed asset purchase expenses & $-9.8209^{* * *}$ & $8.6506^{* * *}$ \\
\hline & $\begin{array}{l}\text { Unused balance carried forward to the } \\
\text { following term }\end{array}$ & $-16.2357^{* * *}$ & $7.5542 * *$ \\
\hline
\end{tabular}

Note: ${ }^{*} p<0.1{ }^{* *} p<0.05,{ }^{* * *} p<0.01$. 
As the stationary test results indicate, we use logged variables in model specification. Because logged variables minimize the influence of outliers, they are appropriate when the distribution of a variable is skewed. Using logged specification, the pooled Ordinary Least Square (POLS) model can be considered. This model can be presented in the following form:

$$
\ln y_{i t}=\alpha+\beta_{i} \ln x_{i t}+\varepsilon_{i t}, \quad i=1, \ldots, n ; t=1, \ldots, t
$$

where $y_{i t}=$ university expenditure vectors, $\alpha=$ constant, and $x_{i t}=$ tuition and government fund.

In the pooled OLS model, it is presumed as $\varepsilon_{i t}=\delta_{i}+e_{i t}$. However, as the data used in this research are panel data, we can consider the panel data regression model. To use the panel data regression model, it is necessary to consider whether $\delta_{i}$ is 0 for all panel entities. This can be done using the Breush Pagan Lagrangran (BPL) Multiplier test. The BPL test shows that panel data analysis is suitable in all variables. Therefore, we decided to use the panel data model, which can be written as follows:

$$
\ln y_{i t}=\alpha+\beta \ln x_{i t}+u_{i}+e_{i t} \quad i=1, \ldots, n ; t=1, \ldots, t
$$

where $y_{i t}=$ university expenditure vectors, $\alpha=$ constant, and $x_{i t}=$ tuition and government fund.

To use the panel data regression model, the Hausman test was conducted to select either the fixed or random effects model. The Hausman test results (Table 6) show that laboratory and fixed asset variable models are more suitable than the random effects model. Except for the two dependent variables, all models indicate that the fixed effect is suitable.

Table 6. Results of the Hausman test.

\begin{tabular}{cccccccc}
\hline $\begin{array}{c}\text { Labor } \\
\text { Costs }\end{array}$ & $\begin{array}{c}\text { Operating } \\
\text { Expenses }\end{array}$ & $\begin{array}{c}\text { Research } \\
\text { Expenses }\end{array}$ & $\begin{array}{c}\text { Laboratory } \\
\text { Fees }\end{array}$ & $\begin{array}{c}\text { Student } \\
\text { Support Fees }\end{array}$ & $\begin{array}{c}\text { Expenditure from } \\
\text { Investments and } \\
\text { Other Assets }\end{array}$ & $\begin{array}{c}\text { Fixed Asset } \\
\text { Purchase Expenses }\end{array}$ & $\begin{array}{c}\text { Unused } \\
\text { Balance Carried } \\
\text { Forward to the } \\
\text { Following Term }\end{array}$ \\
\hline 0.5 & 0.18 & 0.28 & $5.18^{*}$ & 4.16 & 0.72 & $6.37^{*}$ & 1.27 \\
\hline \multicolumn{7}{c}{ Note: ${ }^{*} p<0.1,^{* *} p<0.05,{ }^{* * *} p<0.01}$.
\end{tabular}

For research consistency, this research uses the fixed effect model. To analyze the effects of individual characteristics, the time characteristic effect is used as a dummy variable. The model can be presented as follows:

$$
\ln y_{i t}=\alpha+u_{i}+\beta \ln x_{i t}+e_{i t} i=1, \ldots, n ; t=1, \ldots, t
$$

where $y_{i t}=$ university expenditure vectors, $\alpha=$ constant, $x_{i t}=$ tuition and government fund, and $u_{i}=$ year dummy from 2006 to 2015 .

To investigate the response and behavior of universities to tuition, we estimate the marginal effects of tuition fees and government subsidies. Using polynomial regression, the marginal effects of tuition fees and government subsidies can be presented as follows:

$$
\ln y_{i t}=\alpha+\beta_{1} \ln \pi_{i t}+\beta_{2} \ln \pi_{i t}^{2}+\gamma_{1} \ln \varphi_{i t}+\gamma_{2} \ln \varphi_{i t}^{2}+\delta \ln x_{i t}+u_{i}+\varepsilon_{i t},
$$

where $y_{i t}=$ university expenditure vectors, $\alpha=$ constant, $\beta_{1}=$ tuition fees, $\beta_{2}=$ tuition fee square, $\gamma_{1}=$ government subsidies, and $\gamma_{2}=$ government subside square.

\section{Results}

As a preliminary analysis, this study first examines the rate of change in variables. Tuition fees increased by $2.54 \%$ on average compared to 2007 , but government subsidies increased by $38.65 \%$. The percentage of government subsidies is higher than that of any other variables. This implies that the government provides a monetary incentive to minimize tuition fee increases. Student support fees showed a relatively significant increase compared to other variables, and a decrease after 2012. 
The average rate of research expenses and fixed asset purchase expenses was negative. Labor costs increased by $0.711 \%$ on average, but the rate decreased from 2011 onward. The same pattern was observed in research expenses, fixed asset purchase expenses (Table 7).

Table 7. Change rate of variables (Unit: Percentage).

\begin{tabular}{|c|c|c|c|c|c|c|c|c|c|c|}
\hline & 2007 & 2008 & 2009 & 2010 & 2011 & 2012 & 2013 & 2014 & 2015 & Average \\
\hline Tuition fee & 9.092 & 7.794 & 1.304 & 3.883 & 3.386 & -2.284 & -0.135 & 0.890 & -0.995 & 2.548 \\
\hline Government subsidies & 8.570 & 36.428 & 100.466 & 19.575 & 7.403 & 107.680 & 39.059 & 20.077 & 8.675 & 38.659 \\
\hline Labor costs & 6.505 & 8.107 & 4.458 & 6.322 & 5.941 & 4.715 & 3.357 & 2.310 & 2.461 & 4.908 \\
\hline Operating expenses & 11.252 & 9.158 & 3.802 & 7.533 & 6.180 & 1.036 & 0.628 & 2.441 & -0.980 & 4561 \\
\hline Research expenses & 14.125 & -5.551 & 1.927 & 1.509 & 2.516 & -1.755 & -3.494 & -6.026 & -4.796 & -0.172 \\
\hline Laboratory fees & 4.033 & 6.036 & 8.768 & 6.212 & 8.435 & -3.512 & 0.278 & -1.520 & -3.624 & 2.790 \\
\hline Student support fees & 13.043 & 13.765 & 19.309 & 15.078 & 12.918 & 11.496 & -0.341 & -0.655 & 1.671 & 9.587 \\
\hline $\begin{array}{l}\text { Expenditure from investments } \\
\text { and other assets }\end{array}$ & 30.744 & -4.078 & 5.594 & -4.745 & 11.735 & -32.190 & -2.244 & 5.537 & -2.232 & 0.902 \\
\hline Fixed asset purchase expenses & 8.164 & -4.974 & -5.409 & 9.149 & 0.230 & -5.029 & -9.313 & -4.372 & -9640 & -2.355 \\
\hline $\begin{array}{l}\text { Unused balance carried } \\
\text { forward to the following term }\end{array}$ & 9.675 & 18.619 & 11.833 & 7.212 & 10.941 & -7.980 & -22.097 & -13.076 & -8.729 & 0.711 \\
\hline
\end{tabular}

To analyze the effects of tuition fees on financial management, a fixed model was conducted first. The control variables show different values according to each model. For example, universities with large-scale finances would spend more money on labor, operation, and laboratory costs along with student support fees, whereas there was no difference in research costs, expenditure from investments, and other assets. Relating to the year of establishment, if universities were recently established, they tend to spend less money on labor costs, research costs, laboratory fees, and expenditure from investments and other assets. It is plausible to assume that older universities invest more money on labor and research costs as well as laboratory fees than recently established universities.

Turning to the present study's core focus, the impact of tuition fees turned out to be significant at a level of 0.001 for all dependent variables, except unused balance carried forward to the following term. This result indicates that tuition increase is positively and significantly associated with university financial expenditure. However, the government subsidies variable shows different behaviors, as it is only significant for variables such as labor costs, operating expenses, laboratory fees, and student support fees (Table 8).

We estimated the effect of tuition fee control policy in universities by including a Least Squares Dummy Variable (LSDV) model. We found that universities increased labor costs, operating expenses, and student support fees even after 2011. However, other models, such as research expenses, laboratory fees, and expenditure from investments and other assets, did not show significant differences from 2006. This finding indicates that universities would be more likely to increase their labor costs, operating expenses, and student support fees rather than increasing their research expenses, laboratory fees, and expenditure from investments and other assets. This implies that universities show the tendency to not invest their expenditure in long-term development. With such results, it is logical to assume that spending cuts as a method of financial constraint are a popular strategy [7], but decreases in expenditure are undertaken differently in terms of items.

In addition to the LSDV model, we can test whether the relationship between tuition fees and each expenditure is nonlinear by examining the squared tuition fee variable (Table 9). Holding all other variables constant, if tuition fee proves to be positive and tuition fee square proves to be negative, the average expenditure will first increase as tuition fee increases, but at a diminishing rate. 
Table 8. Results of the fixed model.

\begin{tabular}{|c|c|c|c|c|c|c|c|c|}
\hline & $\begin{array}{l}\text { Labor } \\
\text { Costs }\end{array}$ & $\begin{array}{c}\text { Operating } \\
\text { Expenses }\end{array}$ & $\begin{array}{l}\text { Research } \\
\text { Expenses }\end{array}$ & $\begin{array}{l}\text { Laboratory } \\
\text { Fees }\end{array}$ & $\begin{array}{c}\text { Student } \\
\text { Support Fees }\end{array}$ & $\begin{array}{l}\text { Expenditure from } \\
\text { Investments and } \\
\text { Other Assets }\end{array}$ & $\begin{array}{l}\text { Fixed Asset } \\
\text { Purchase } \\
\text { Expenses }\end{array}$ & $\begin{array}{l}\text { Unused Balance } \\
\text { Carried forward to } \\
\text { the Following Term }\end{array}$ \\
\hline Variables & $\begin{array}{l}\text { Estimate } \\
\text { (Std. Error) }\end{array}$ & $\begin{array}{c}\text { Estimate } \\
\text { (Std. Error) }\end{array}$ & $\begin{array}{l}\text { Estimate } \\
\text { (Std. Error) }\end{array}$ & $\begin{array}{l}\text { Estimate } \\
\text { (Std. Error) }\end{array}$ & $\begin{array}{l}\text { Estimate } \\
\text { (Std. Error) }\end{array}$ & $\begin{array}{l}\text { Estimate } \\
\text { (Std. Error) }\end{array}$ & $\begin{array}{l}\text { Estimate } \\
\text { (Std. Error) }\end{array}$ & $\begin{array}{c}\text { Estimate } \\
\text { (Std. Error) }\end{array}$ \\
\hline 2007 & $\begin{array}{l}-0.01476 \\
(0.02828)\end{array}$ & $\begin{array}{c}0.02942 \\
(0.03829)\end{array}$ & $\begin{array}{l}-0.29437 \\
(0.21530)\end{array}$ & $\begin{array}{l}-0.03216 \\
(0.05692)\end{array}$ & $\begin{array}{c}0.07339 \\
(0.08135)\end{array}$ & $\begin{array}{c}0.19713 \\
(0.27129)\end{array}$ & $\begin{array}{l}-0.0895 \\
(0.10077)\end{array}$ & $\begin{array}{c}0.06827 \\
(0.33895)\end{array}$ \\
\hline 2008 & $\begin{array}{l}-0.00123 \\
(0.02891)\end{array}$ & $\begin{array}{c}0.05373 \\
(0.03914)\end{array}$ & $\begin{array}{l}-0.37764 \\
(0.22010)\end{array}$ & $\begin{array}{l}-0.04957 \\
(0.05819)\end{array}$ & $\begin{array}{c}0.08899 \\
(0.08316)\end{array}$ & $\begin{array}{c}0.26373 \\
(0.27734)\end{array}$ & $\begin{array}{l}-0.03832 \\
(0.10302)\end{array}$ & $\begin{array}{c}0.32757 \\
(0.34651)\end{array}$ \\
\hline 2009 & $\begin{array}{c}0.02181 \\
(0.03016) \\
\end{array}$ & $\begin{array}{c}0.06809 \\
(0.04084) \\
\end{array}$ & $\begin{array}{l}-0.19920 \\
(0.22962) \\
\end{array}$ & $\begin{array}{l}-0.00080 \\
(0.06070) \\
\end{array}$ & $\begin{array}{c}0.17710 \\
(0.08676) \\
\end{array}$ & $\begin{array}{c}0.22303 \\
(0.28933) \\
\end{array}$ & $\begin{array}{l}-0.05294 \\
(0.10747) \\
\end{array}$ & $\begin{array}{l}0.78988^{*} \\
(0.36149) \\
\end{array}$ \\
\hline 2010 & $\begin{array}{c}0.04474 \\
(0.03096)\end{array}$ & $\begin{array}{l}0.10817^{*} \\
(0.04192)\end{array}$ & $\begin{array}{l}-0.34752 \\
(0.23570)\end{array}$ & $\begin{array}{c}0.02670 \\
(0.06231)\end{array}$ & $\begin{array}{l}0.25682 * \\
(0.08905)\end{array}$ & $\begin{array}{c}0.45069 \\
(0.29699)\end{array}$ & $\begin{array}{l}-0.06073 \\
(0.11032)\end{array}$ & $\begin{array}{l}1.04254^{* *} \\
(0.37107)\end{array}$ \\
\hline 2011 & $\begin{array}{l}0.08719^{* *} \\
(0.03137)\end{array}$ & $\begin{array}{c}0.16186^{* * *} \\
(0.04247)\end{array}$ & $\begin{array}{l}-0.13834 \\
(0.23882)\end{array}$ & $\begin{array}{c}0.09393 \\
(0.06314)\end{array}$ & $\begin{array}{c}0.33886^{* * *} \\
(0.09023)\end{array}$ & $\begin{array}{c}0.29161 \\
(0.30092)\end{array}$ & $\begin{array}{l}-0.06897 \\
(0.11178)\end{array}$ & $\begin{array}{l}1.18069^{* *} \\
(0.37598)\end{array}$ \\
\hline 2014 & $\begin{array}{c}0.19776^{* * *} \\
(0.03460)\end{array}$ & $\begin{array}{c}0.16181^{* * *} \\
(0.04685)\end{array}$ & $\begin{array}{l}-0.33982 \\
(0.26341)\end{array}$ & $\begin{array}{c}0.01604 \\
(0.06964)\end{array}$ & $\begin{array}{l}0.29624^{* *} \\
(0.09953)\end{array}$ & $\begin{array}{l}-0.19081 \\
(0.33191)\end{array}$ & $\begin{array}{c}-0.37022 \text { ** } \\
(0.12329)\end{array}$ & $\begin{array}{c}0.57306 \\
(0.41470)\end{array}$ \\
\hline 2015 & $\begin{array}{c}0.22787^{* * *} \\
(0.03478) \\
\end{array}$ & $\begin{array}{c}0.15175^{* * *} \\
(0.04709)\end{array}$ & $\begin{array}{l}-0.40713 \\
(0.26478)\end{array}$ & $\begin{array}{c}0.00869 \\
(0.07000)\end{array}$ & $\begin{array}{l}0.30619 * * \\
(0.10004)\end{array}$ & $\begin{array}{c}0.19899 \\
(0.33363)\end{array}$ & $\begin{array}{c}-0.55517^{* * *} \\
(0.12393)\end{array}$ & $\begin{array}{c}0.40590 \\
(0.41684)\end{array}$ \\
\hline Size 2 & $\begin{array}{c}0.00568 \\
(0.03377)\end{array}$ & $\begin{array}{c}-0.16353^{* * *} \\
(0.04573)\end{array}$ & $\begin{array}{c}1.07321^{* * *} \\
(0.25712)\end{array}$ & $\begin{array}{c}-0.39731 \text { *** } \\
(0.06797)\end{array}$ & $\begin{array}{c}0.12522 \\
(0.09715)\end{array}$ & $\begin{array}{c}0.02251 \\
(0.32399)\end{array}$ & $\begin{array}{l}-0.30039^{*} \\
(0.12035)\end{array}$ & $\begin{array}{c}0.49460 \\
(0.40480)\end{array}$ \\
\hline Size 3 & $\begin{array}{c}0.20578^{* * *} \\
(0.04993)\end{array}$ & $\begin{array}{c}-0.19757^{* *} \\
(0.06761)\end{array}$ & $\begin{array}{l}0.84919 * \\
(0.38016)\end{array}$ & $\begin{array}{c}-0.46930 * * * \\
(0.10050)\end{array}$ & $\begin{array}{c}0.16738 \\
(0.14364)\end{array}$ & $\begin{array}{l}-0.57829 \\
(0.47902)\end{array}$ & $\begin{array}{l}-0.24054 \\
(0.17794)\end{array}$ & $\begin{array}{l}1.27007^{*} \\
(0.59850)\end{array}$ \\
\hline $\begin{array}{l}\text { Finance } \\
\text { size } 2\end{array}$ & $\begin{array}{l}-0.08645 \\
(0.07106)\end{array}$ & $\begin{array}{l}-0.04505 \\
(0.09622)\end{array}$ & $\begin{array}{c}-1.26558^{*} \\
(0.54104)\end{array}$ & $\begin{array}{l}-0.12601 \\
(0.14303)\end{array}$ & $\begin{array}{c}0.25969 \\
(0.20442)\end{array}$ & $\begin{array}{c}-1.34524^{*} \\
(0.68173)\end{array}$ & $\begin{array}{c}-0.895411^{* * *} \\
(0.25324)\end{array}$ & $\begin{array}{c}-3.43467 * * * \\
(0.85177)\end{array}$ \\
\hline tuition fee & $\begin{array}{c}0.71858^{* * *} \\
(0.02958)\end{array}$ & $\begin{array}{l}0.739^{* * *} \\
(0.04006)\end{array}$ & $\begin{array}{c}1.31021 * * * \\
(0.22523)\end{array}$ & $\begin{array}{c}0.91076^{* * *} \\
(0.05954)\end{array}$ & $\begin{array}{c}0.72633^{* * *} \\
(0.08510)\end{array}$ & $\begin{array}{c}1.57892^{* * *} \\
(0.28380)\end{array}$ & $\begin{array}{c}0.65774 * * * \\
(0.10542)\end{array}$ & $\begin{array}{l}-0.32858 \\
(0.35459)\end{array}$ \\
\hline $\begin{array}{l}\text { government } \\
\text { subsidies }\end{array}$ & $\begin{array}{c}0.01338^{* * *} \\
(0.00506)\end{array}$ & $\begin{array}{c}0.02026^{* * *} \\
(0.00685)\end{array}$ & $\begin{array}{c}0.01060 \\
(0.03851)\end{array}$ & $\begin{array}{l}0.02347^{*} \\
(0.01018)\end{array}$ & $\begin{array}{c}0.07606^{* * *} \\
(0.01455)\end{array}$ & $\begin{array}{l}-0.07408 \\
(0.04852)\end{array}$ & $\begin{array}{c}0.00344 \\
(0.01802)\end{array}$ & $\begin{array}{l}-0.02347 \\
(0.06062)\end{array}$ \\
\hline
\end{tabular}

Note: ${ }^{*} p<0.1,{ }^{* *} p<0.05,{ }^{* * *} p<0.01$.

The results of polynomial regression for labor costs indicate that tuition fee proves negative, whereas tuition fee square proves positive. This implies that labor costs will increase as the tuition fees increase, but at an increasing rate. We found similar results in the operating expenses and student support fee models. However, the negative tuition fee squared coefficient in research expenses, expenditure from investments and other assets, and unused balance carried forward to the following term models indicate that the effect of tuition fees diminishes as tuition fees increase. Government subsidies provide different results compared to tuition fees. It is important to note that the research cost, expenditure from investments and other assets, and unused balance carried forward to the following term models show different signs between tuition fees and government subsidies. 
Table 9. Results of the polynomial regression model.

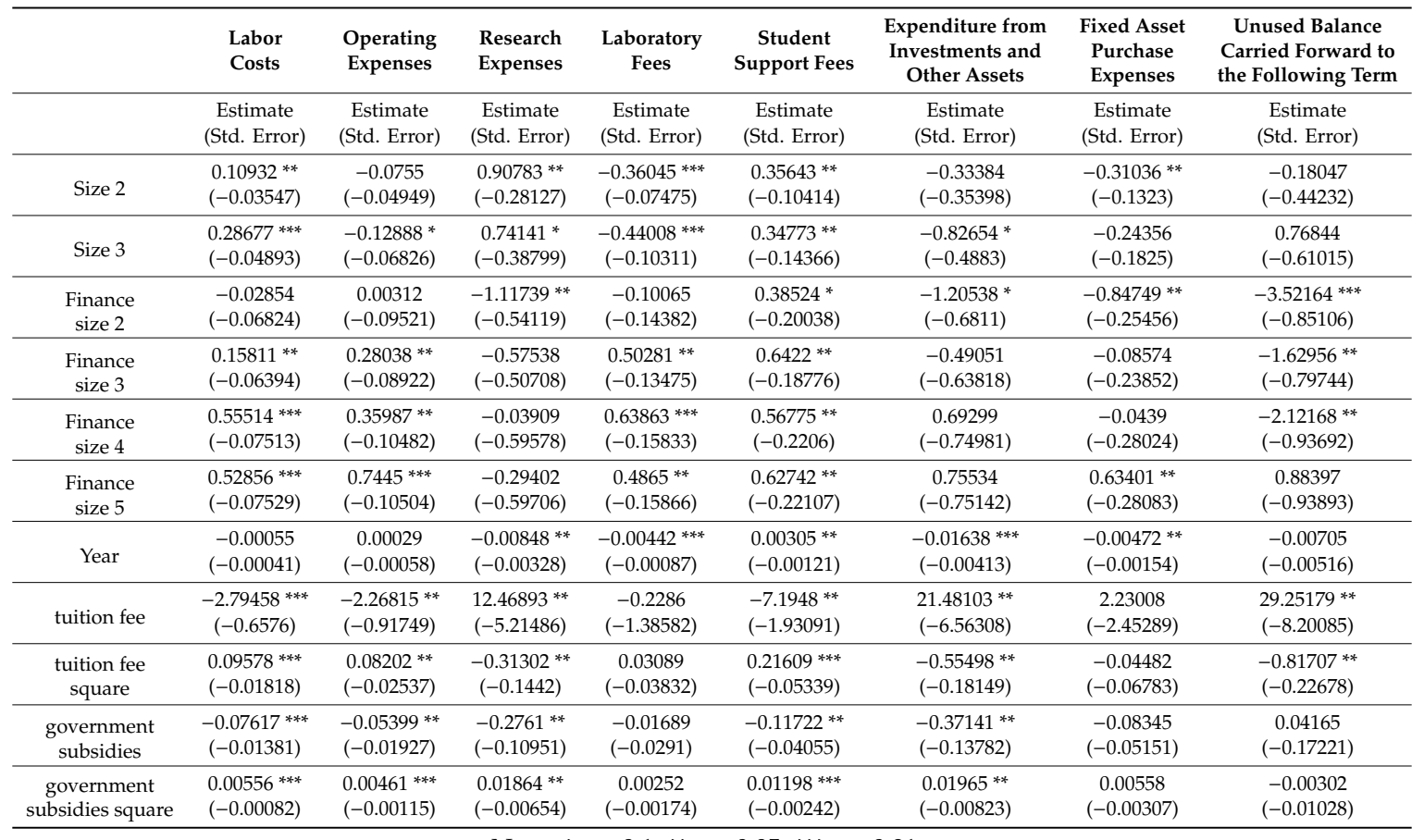

Note: ${ }^{*} p<0.1,{ }^{* *} p<0.05,{ }^{* * *} p<0.01$.

\section{Discussion}

Tuition fee increase has become an important issue in Korea since the early 2000s. Along with public concerns about tuition fees, the government made efforts to address these problems with the amendment of the Higher Education Act. Using data from the financial statements of private universities, this study aimed to provide important insight into higher education policies while examining the impact of the tuition fee policy on university financial management. This study briefly examines the average tuition increase in percentage change by year. The findings revealed that government tuition fee policies have been effective in controlling tuition fees after 2011 . While the tuition fee increase rate slowed down after 2011, government subsidies showed a critical increase rate. The tuition fee control policy has major implications for universities in Korea because tuition is the largest source of revenue for most universities, comprising $65 \%$ of their total revenue. With this background, this study analyzed the effects of tuition fee control on university expenditures, such as labor costs, operating expenses, research expenses, laboratory fees, and student support fees. The effect of tuition fee control was examined using the LSDV model. The results indicate that universities increase their spending in some items, such as labor costs, operating expenses, and student support fees, while there is no difference in research expenses, laboratory fees, and expenditure from investments and other assets. Based on the principal-agency theory, the findings regarding labor costs and operating expenses are intuitive, but those pertaining to student support fee increases are not. These results can be explained by considering government subsidies. As mentioned above, the Korean government has increased their subsidies to enhance university capability in a competitive situation. Most government subsidies include student capability enhancement projects, and these subsidies flow into universities through the university matching the fund. In addition, government subsidies increased through scholarships for students, and thus expenditure on students also increased. In this context, it is plausible to understand that the increase in student support fees after 2011 arose from government subsidies. However, there is no significant increase in research expenses, laboratory costs, and expenditure from investments and other assets. In the case of fixed asset purchase expenses, we found that expenditure decreased after 2011. These results prove the existence of a moral hazard in university expenditure under financial constraints. The labor costs of faculty and staff are essential for education and research, 
and increasing these costs does not necessarily mean that education and research were neglected. It is natural for universities to use selective reinvestment because comprehensive coverage is considered unviable for universities in a financial constraint situation. These differences may result from the differences in universities' priorities and organizations' purposes. However, it is important to note the universities' behaviors and responses. When universities face financial constraints, it is said that some initiatives, such as decreasing the number of full-time faculty members, decreased course and program offerings, and reduced library and student services are undertaken in the name of cost reduction [7]. However, this study provides different results, namely that universities seek other methods to avoid financial constraints. The results indicate that universities cut their spending in specific areas; however, in certain areas, universities tended to pursue benefits such as labor and operating costs.

These findings added to our understanding about universities' characteristics. One perspective on universities' characteristics considers the university as an academic community that shares the same values and norms and makes consensual decisions [47]. Universities are operated as per the norms and values of learning that are shared among not only the professors, but also other members of the university [48]. Another perspective views universities as complex organizations with an official hierarchy and a series of regulations. In these perspectives, all universities have official communication channels and bureaucratic stages of authority [49]. However, universities have multiple members in their organizational structures, such as the president, chairman, board of directors, professors, students, and staff, and have complicated decision-making and execution processes that reflect their education and research capabilities. In addition, as Liefner [30] notes, there are numerous principals and agents in higher education institutions. Furthermore, we find that professors themselves have different goals because they increase their labor cost while decreasing research expenditure. This study provides the evidence that members of a university have different goals and preferences [45], and there may be conflicts in their preferences and priorities.

In addition to the LSDV model, the polynomial regression model provides the result that universities behave differently according to resources, whether they are tuition fees or government subsidies. The labor costs, operating expenses, and student support fees show an increase as the tuition fees increase with an increasing rate for both tuition fees and government subsidies. Research expenses and expenditures from investments and other assets increase as tuition fees increase with a diminishing rate. In contrast, research expenses and expenditure from investments and other assets increase as government subsidies increase with an increasing rate. It is important to note that these results are relevant to principal-agency theory. There is the relationship between the government as principal and the university as agent [50]. Principal-agency theory can be used to understand motivations and the impact of competing demands on the decision-making of universities [51]. Applying the principal and agent model, this study provides the evidence that universities have different organizational interests according to resources. In a situation where the introduction of tuition fee control policy could be seen as a threat to universities [2], this study reveals the pattern that universities raise as much money as they can and spend all the money from government subsidies: The so-called revenue theory of cost [43]. However, with tuition fees, universities show different patterns in specific expenditures, such as research expenses and expenditure from investments and other assets. This result provides the evidence that the attempt to integrate the perspective of principal and agency theory into the sphere of financial management between government and university is successful [51]. It is important to note some of the key perceptions and insights that principal and agency theory could offer for university financial management.

In this context, it is necessary to adapt the performance-based research funding system. In Korea, the government employs a performance-based system in the area of university education, while there is no systematic performance-based system for university research [52]. The performance-based funding system reduces the risk of adverse selection and moral hazard problems. This system makes universities more autonomous and increases productivity along with more strategic university management [53]. 
At the university level, it is necessary to rethink universities' planning and management practices from a general fund approach and centralized, incremental budgeting to an incentive-based budget system or Responsibility Center Management [25]. Until now, most Korean universities have used centralized and incremental budgeting. Given that goal conflicts and information asymmetries are relevant in the university context, it is necessary to improve decision-making through better information and an incentive mechanism. An incentive-based budget system provides better information for the unit level to increase planning capacity [54]. In addition, an incentive-based system devolves budget responsibility to academic units to create the incentive for academic units to generate revenues and decrease costs [29].

\section{Conclusions}

The rapid growth of higher education tuition fees has led to greater interest in higher education policy and scholarship. The Korean government amended the Higher Education Act to strengthen control over tuition fee increase and set a limit on the increase, and it has also been implementing policies to control tuition fee increase through various financial projects. In this situation, this study investigated the effect of the tuition fee control policy and examined the characteristics of financial management in universities under tuition fee constraints.

An analysis was conducted on the income and expenditure structure of university finance. The results showed that the increase rate of tuition fees decreased after 2011, but that on government subsidies increased significantly. Government policy to increase subsidies tends to be suppressing tuition increase. In addition, this study further examined the characteristics of financial management in universities using the principal-agent model. This study examined the effects of tuition fees and government subsidies on dependent variables such as labor cost, operating expenses, and so on. Using an LSDV model, this study investigated the effects of tuition fees on individual models. The LSDV results indicate that universities increase labor costs, operating expenses, and student support fees. Relating to student support fee increase, this study explains that this increases through government subsidies and scholarships. In the case of research expenses, laboratory fees, and expenditure from investment and other assets, we found no difference from 2006. Using polynomial regression, this study found that universities tend to behave differently according to source, whether it is from government or tuition. Applying the principal and agent theory, this study suggested the necessity of a performance-based research system in research at government levels and an incentive-based budget system in universities.

Despite such significance, this study has some limitations. While it analyzed the characteristics of financial management under tuition fee constraints, it failed to examine the changes in financial structure that may have been caused by tuition fee constraints. It is necessary to examine how financial structures, such as financial stability, growth, and soundness, have changed due to tuition fee constraints. Furthermore, while this study examined the characteristics of financial management under tuition fee constraints, it did not review financial expenditure related to university performance. It is thus necessary to review whether the increase or decrease of expenditure relates to university performance.

Author Contributions: Conceptualization, Y.-H.L.; methodology, Y.-H.L.; validation, Y.-H.L.; writing-original draft preparation, Y.-H.L.; writing-review and editing, K.-S.K. and K.-H.L.; funding acquisition, K.-H.L. All authors have read and agreed to the published version of the manuscript.

Funding: This research was supported by Kangwon National University.

Conflicts of Interest: The authors declare no conflicts of interest. 


\section{References}

1. Boehner, J.A.; McKeon, H.P. The College Cost Crisis: A Congressional Analysis of College Costs and Implications for America's Higher Education System. 2003. Available online: http://www2.bgsu.edu/ downloads/finance/file17013.pdf (accessed on 20 April 2020).

2. Kim, M.M.; Ko, J. The impacts of state control policies on college tuition increase. Educ. Policy 2015, 29, 815-838. [CrossRef]

3. Mumper, M. State efforts to keep public colleges affordability in the face of fiscal stress. In The Finance of Higher Education: Theory, Research, Policy E Practice; Paulsen, M.B., Smart, J.C., Eds.; Agathon Press: New York, NY, USA, 2001; pp. 321-354.

4. Haptman, A.M. The College Tuition Spiral: An Examination of Why Charges Are Increasing; Macmillan and the American Council on Education and The College Board: New York, NY, USA, 1990.

5. Okunade, A.A. What factors influence state appropriations for public higher education in the United States? J. Educ. Financ. 2004, 30, 123-138.

6. Fisher, D.; Rubenson, K.; Jones, G.; Shanahan, T. The political economy of post-secondary education: A comparison of British Columbia, Ontario and Québec. High. Educ. 2009, 57, 549-566. [CrossRef]

7. Deering, D.; Sa, C.M. Financial management of Canadian universities: Adaptive strategies to fiscal constraints. Tert. Educ. Manag. 2014, 20, 207-224. [CrossRef]

8. Gumport, P. Academic restructuring: Organizational change and institutional imperatives. Higher Educ. 2000, 39, 67-91. [CrossRef]

9. Paulsen, M.B. The economics of human capital and investment in higher education. In The Finance of Higher Education: Theory, Research, Policy and Practice; Paulsen, M.B., Smart, J.C., Eds.; Agathon Press: New York, NY, USA, 2001; pp. 55-94.

10. Dearden, L.; Fitzsimons, E.; Wyness, G. The Impact of Tuition Fees and Support on University Participation in the UK; Centre for the Economics of Education: London, UK, 2011; p. 126.

11. Kivistö, J.A. Agency Theory as a Framework for the Government-University Relationship; Higher Education Group/Tampere University Press: Tampere, Finland, 2007.

12. Caruana, J.; Brusca, I.; Caperchione, E.; Cohen, S.; Manes Rossi, F. (Eds.) Financial Sustainability of Public Sector Entities: The Relevance of Accounting Frameworks; Palgrave Macmillan: London, UK, 2019.

13. Di Carlo, F.; Modugno, G.; Agasisti, T.; Catalano, G. Changing the Accounting System to Foster Universities' Financial Sustainability: First Evidence from Italy. Sustainability 2019, 11, 6151. [CrossRef]

14. Kane, T.J.; Orszag, P.R. Funding Restrictions at Public Universities: Effects and Policy Implications; Working Paper; Brookings Institution: Washington, DC, USA, September 2003.

15. Burgess, B. Evaluating the polices that lead to substantial tuition variation at public land-grant universities. Plan. High. Educ. 2011, 39, 25-33.

16. Boatman, A.; L'Orange, H. State Tuition, Fees, and Financial Assistance Policies for Public Colleges and Universities; 2005-06; State Higher Education Executive Officers: Denver, CO, USA, 2006.

17. Crowford, C.; Dearden, L. The Impact of the 2006-2007 HE Finance Reforms on HE Participation; BIS Research Paper, no.13; Department for Business, Innovation and Skills: London, UK, 2010.

18. Görgen, K.; Schienle, M. Evaluating Effects of Tuition Fees: Lasso for the Case of Germany. 2019. Available online: https://arxiv.org/pdf/1909.08299.pdf (accessed on 15 December 2019).

19. Bahrs, M.; Siedler, T. University Tuition Fees and High School Students' Educational Intentions; Discussion Paper Series, No. 12053; IZA Institute of Labor Economics: Bonn, Germany, 2018.

20. Gawellek, B.; Süssmuth, B.; Singh, D. Tuition fees and instructional quality. Econ. Bull. 2016, 36, 84-91.

21. Yoo, J.S. Influence of Half-Tuition Policy and Political Economy; Korea Economic Research Institute: Seoul, Korea, 2014.

22. McLendon, M.K.; Hearn, J.C.; Mokher, C.G. Partisans, professionals, and power: The role of political factors in state higher education funding. J. High. Educ. 2009, 80, 686-713. [CrossRef]

23. Leslie, L.L.; Rhoades, G. Rising administrative costs: Seeking explanations. J. High. Educ. 1995, 66, 187-212. [CrossRef]

24. Cheslock, J.J.; Gianneschi, M. Replacing state appropriations with alternative revenue sources: The case of voluntary support. J. High. Educ. 2008, 79, 208-229. [CrossRef] 
25. Hearn, J.C.; Lewis, D.R.; Kallsen, L.; Holdsworth, J.A.; Jones, L.M. “Incentives for managed growth": A case study of incentives-based planning and budgeting in a large public research university. J. High. Educ. 2006, 77, 286-316.

26. Gros Louis, K.R.R.; Thompson, M. Responsibility center budgeting and management at Indiana University. In Incentive-Based Budgeting Systems in Public Universities; Priest, D.M., Becker, W.E., Hossler, D., John, E.P.S., Eds.; E. Elgar: Cheltenham, UK; Northhampton, MA, USA, 2002; pp. 93-108.

27. Adams, E.M. Rationality in the Academy Why Responsibility Center Budgeting Is a Wrong Step down the Wrong Road. Chang. Mag. High. Learn. 1997, 29, 58-61. [CrossRef]

28. Murray, B. Can academic values mesh with fiscal responsibility? Business-like budgeting clashes with team spirit, some psychologists say. Monit. Psychol. 2000, 31, 1-5.

29. Jaquette, O.; Kramer, D.A.; Curs, B.R. Growing the Pie? The Effect of Responsibility Center Management on Tuition Revenue. J. High. Educ. 2018, 89, 637-676. [CrossRef]

30. Liefner, I. Funding, resource allocation and performance in higher education system. High. Educ. 2003, 46, 469-489. [CrossRef]

31. Tandberg, D.A.; Fowles, J.T.; McLendon, M.K. The governor and the state higher education executive officer: How the relationship shapes state financial support for higher education. J. High. Educ. 2017, 88, 110-134. [CrossRef]

32. Gornitzka, Å.; Stensaker, B.; Smeby, J.-C.; de Boer, H. Contract arrangements in the Nordic countries. Solving the efficiency/effectiveness dilemma? High. Educ. Eur. 2004, 29, 87-101. [CrossRef]

33. Jeong, J.H.; Ban, S.J. Study on the reform of a tuition setting method in higher education. J. Educ. Adm. 1999, 17, 283-326. (In Korean)

34. Lee, J.M.; Lee, S.D. An analysis on issues and logics on New National Student Aid Program. J. Educ. Adm. 2012, 30, 79-104.

35. Ross, S.A. The economic theory of agency: The principal's problem. Am. Econ. Rev. 1973, 63, $134-139$.

36. Jensen, M.C.; Meckling, W.H. Theory of the firm: Managerial behavior, agency costs and ownership structure. J. Financ. Econ. 1976, 3, 305-360. [CrossRef]

37. Pratt, J.W.; Zeckhauser, R.J. Principals and Agents: The Structure of Business; Harvard University Press: Cambridge, MA, USA, 1985.

38. Arrow, K. The economics of agency. In Principals and Agents: The Structure of Business; Pratt, J., Zeckhauser, R., Eds.; Harvard University Press: Cambridge, MA, USA, 1985; pp. 37-51.

39. Lowry, R. Governmental structure, trustee selection, and public university prices and spending. Am. J. Political Sci. 2001, 45, 845-861. [CrossRef]

40. Baldridge, J.V. Power and Conflict in the University: Research in the Sociology of Complex Organizations; Wiley: New York, NY, USA, 1971.

41. Enders, J.; Fulton, O. Higher Education in a Globalising World: International Trends and Mutual Observations a Festschrift in Honour of Ulrich Teichler; Springer Netherlands: Dordrecht, The Netherlands, 2002.

42. Winston, G.C. Subsidies, hierarchy and peers: The awkward economics of higher education. J. Econ. Perspect. 1999, 13, 13-36. [CrossRef]

43. Bowen, H.R. The costs of Higher Education: How much Do Colleges and Universities Spend per Student and How Much Should They Spend; Jossey-Bass: San Francisco, CA, USA, 1980.

44. Garvin, D.A. The Economics of University Behavior; Academic Press: New York, NY, USA, 1980.

45. Salancik, G.; Pfeffer, J. The bases and use of power in organizational decision making. Adm. Sci. Q. 1974, 19, 453-473. [CrossRef]

46. Levin, A.; Lin, C.F.; Chu, J. Unit Root Tests in Panel Data: Asymptotic and Finite Sample Properties. J. Econometrics. 2002, 98, 1-24. [CrossRef]

47. Millett, J.D. Academic Community: An Essay on Organization; McGraw-Hill: New York, NY, USA, 1962.

48. Clark, B.R. The organizational saga in higher education. Adm. Sci. Q. 1972, 17, 178-184. [CrossRef]

49. Stroup, H. Bureaucracy in Higher Education; The Free Press: New York, NY, USA, 1966.

50. Ahmad, A.R.; Farley, A.; Naidoo, M. Analysis of government-university relationship from the perspective of agency theory. J. Educ. Pract. 2012, 3, 12-22.

51. Lane, J.E.; Kivisto, J.A. Interest, information and incentives in higher education: Principal-agent theory and is potential application to the study of higher education governance. In Higher Education: Handbook of Theory and Research; Springer International Publishing: Cham, Switzerland, 2008. 
52. Lee, Y.H.; Kim, H.K. Financial support and university performance in Korea universities: A panel data approach. Sustainability 2019, 11, 5871. [CrossRef]

53. Hicks, D. Performance-based university research funding systems. Res. Policy 2016, 41, 251-261. [CrossRef]

54. Curry, J.R.; Laws, A.L.; Strauss, J.C. Responsibility Center Management: A Guide to Balancing Academic Entrepreneurship with Fiscal Responsibility; National Association of College and University Business Officers: Washington, DC, USA, 2013.

(C) 2020 by the authors. Licensee MDPI, Basel, Switzerland. This article is an open access article distributed under the terms and conditions of the Creative Commons Attribution (CC BY) license (http://creativecommons.org/licenses/by/4.0/). 